\title{
Perubahan Kurikulum 2013 Terhadap Sikap Profesional Guru Penjasorkes Sekolah Menengah Pertama di Kabupaten Karawang
}

\author{
Fahrudin \\ Universitas Singaperbangsa, H.S Ronggowaluyo Teluk Jambe Timur, Karawang 41361
}

*Corresponding author: arrufahrudin@gmail.com

\section{ARTICLE INFO}

\section{Article history:}

Received 27 July 16

Received in revised form 15 August 16

Accepted 08 September 16

Keywords:

Curriculum 2013; Physical Education

Teacher; Professional Attitude

\begin{abstract}
A B S TR A C T
The purpose of this study is to determine how much percentage of implementation of the curriculum in 2013 positive or negative influence on the attitudes of Professional Physical Education (PE) teachers at Junior High School in District Rengasdengklok Karawang regency. The attitude of the teacher is behavior that tends to settle on himself a teacher in performing tasks related to education including teaching duties. Implementation of curriculum changes that lead to success or failure of the implementation of the curriculum depends on the attitude of teachers in receipt of such reforms as the spearhead of achieving national education goals. The research method used a qualitative approach to the type of ethnographic research. Researcher using purposive sampling technique and Snowball Sampling. Research location at Rengasdengklok District of Karawang, Research started from the participant of PE teacher who served in Junior High School 1 Kutawaluya, Karawang, West Java. The results obtained from the field, namely: 1) Most of the informants stated that changes curriculum 2013 bring positive impact on PE Teachers' Professional Attitude at Junior High School in Karawang 2) A small number of informants stated, Changes Curriculum 2013 bring negative influence on PE teachers' Professional Attitude at Junior High School in the Karawang regency.
\end{abstract}

\section{Pendahuluan}

Dalam perubahan kurikulum apapun bentuknya yang tidak boleh dilupakan adalah perubahan sikap mental guru dimana perubahan ini merupakan fondasi dasar dari keberhasilan target capaian dari kurikulum yang dicanangkan. Adapun sikap mental yang perlu ditingkatkan adalah sebagai berikut:

Pertama: Tingkatkan rasa cinta kasih kepada peserta didik ,dan perhatikan tuntutan capaian standar kompetensi dari kurikulum. Kebutuhan dasar psikologis siswa adalah diakui keberadaannya,dihargai pendapatnya dan merasakan mendapat cinta kasih yang tulus, jika siswa terpenuhi kebutuhan dasar psikologisnya akan lebih mudah untuk diarahkan dan diajak komunikasi sekaligus mudah bagi guru bersangkutan malakukan upaya meningkatakan kompetensi diri siswa sekaligus melaksanakan proses evaluasi. Mengingat tututan kurikulum 2013 adalah pola pembelajaran berbasis massal menjadi kebutuhan pelanggan (users) dengan memperkuat pengembangan potensi khusus yang dimiliki setiap peserta didik.

Kedua : Pekalah terhadap perubahan dan bersiaplah untuk membimbing siswa. Perubahan yang terjadi pada kurikulum 2013 adalah pola pembelajaran terisolasi menjadi pembelajaran secara jejaring (peserta didik dapat menimba ilmu dari siapa saja dan dari mana saja yang dapat dihubungi serta diperoleh melalui internet. Sebagai guru perlu memiliki kepekaan terhadap perubahan pola kognitif siswa dalam mempelajari sesuatu diera serba canggih ini dari sekedar menghafal menjadi mencari, menganalisa, uji coba dan mengambil kesimpulan. Kepekaan terhadap peranan emosi siswa dalam belajar, situasi menyenangkan, tidak tertekan, gembira dan memiliki pengalaman belajar langsung menjadi sandaran utama keberhasilan pembelajaran Dan kepekaan guru dalam psikomotor atau perilaku siswa terutama dalam search analysis skill dalam pemanfatan media dan sumber belajar akan mengarahkan siswa untuk dapat belajar secara mandiri.

Ketiga ; Setiap siswa adalah Unik, Utamakanlah untuk dapat membantu setiap siswa mendapatkan Pembelajarannya dalam setiap pertemuan kelas. Ilmu dan pengetahuan yang menunjang profesi itu selalu berkembang sesuai dengan kemajuan zaman. Sehingga dapat dirumuskan bahwa Sikap guru adalah tingkah laku yang cenderung menetap pada diri seorang pengajar dalam melakukan tugas-tugas yang terkait dengan kependidikan termasuk tugas mengajarnya. Melihat situasi di lapangan masih banyak guru penjasorkes yang belum siap terhadap perubahan-perubahan kurikulum yang semakin tinggi sering berubah-ubah yang cenderung membingungkan para guru dalam mengimplementasikannya dalam administrasi dan proses pembelajarannya. Pembelajaran yang berpusat pada siswa justru lebih memacu guru lebih aktif untuk menyeimbangkan siswa dalam pencarian materi pembelajarannya di dalam TIK. Sedangkan masih tidak sedikit guru penjasorkes yang tergolong kurang paham dengan penggunaan sistem TIK tersebut. Berdasarkan uraian di atas, maka penulis merumuskan masalah penelitian sebagai berikut.

1. Seberapa besar perubahan kurikulum 2013 berpengaruh positif terhadap sikap profesional guru Penjasorkes sekolah menengah pertama di Kabupaten Karawang?

2. Seberapa besar perubahan kurikulum 2013 berpengaruh negatif terhadap sikap profesional guru Penjasorkes sekolah menengah pertama di Kabupaten Karawang?

\section{A. Perubahan Kurikulum}

Perubahan adalah transformasi dari keadaan yang sekarang menuju keadaan yang diharapkan di masa yang akan datang, suatu keadaan yang lebih baik. Perubahan dalam skala yang sangat luas dikemukakan oleh Toffler (1980:23) yang menyatakan bahwa telah terjadi gelombang pertama sebagai revolusi pertanian, disusul dengan gelombang kedua berupa revolusi industri.

Dalam melihat adanya gejala perubahan, terdapat beragam pandangan tentang bagaimana terjadinya perubahan tersebut, ada yang 
memandang perubahan sebagai suatu proses, ada yang melakukan dalam bentuk tahapan, ada pula yang melakukan dengan pendekatan sistem, dan ada pula yang mengajukan perubahan sebagai suatu model.

\section{Urgensi Perubahan Kurikulum}

Perubahan-perubahan atau penyempurnaan kurikulum yang terjadi di Indonesia sejak bernama Rentjana Pembelajaran 1947 hingga Kurikulum Tingkat Satuan Pendidikan (KTSP) tahun 2006 selalu dibarengi dengan argumen-argemen ilmiah, pendekatan-pendekatan mutakhir, lengkap dengan background teori-teori belajar terbaru, dan rasional yang tidak terbantahkan. Meski tidak dapat dipungkiri, selalu ada alasan- lain yang mengiringi perubabahan kurikulum di Indonesia.

Penyesuaian dengan perkembangan zaman, adalah salah satu alasan yang sering diwacanakan ketika perubahan kurikulum terjadi. Perubahan dari kurikulum 1947 yang memberi perhatian pada pembentukan karakter manusia yang berdaulat dan sejajar dengan bangsa lain, disempurnakan menjadi kurikulum 1952 dengan nama Rentjana Pembelajaran Terurai lebih difokuskan pada isi pelajaran yang harus berhubungan dengan kebutuhan hidup sehari-hari adalah contoh perubahan atau penyempurnaan kurikulum karena penyesuaian dengan perkembangan zamanpun perubahan kurikulum 1975 yang mengusung satuan pelajaran (SP), mengenalkan tujuan instruksional umum (TIU), tujuan instruksional khusus (TIK), materi pelajaran, alat belajar, kegiatan belajar-mengajar, serta evaluasi menjadi kurikulum 1984 dengan pendekatan prosesnya meski tetap memperhatikan tujuan-tujuan instruksional sehingga melahirkan model cara belajar siswa aktif (CBSA). CBSA dipilih karena pada masa itu berkembang metode pembelajaran aktif (active learning).

Alasan politis seringkali juga menjadi penyebab perubahan atau penyempurnaan kurikulum. Perubahan kurikulum 1964 dengan Rencana Pendidikan yang menekankan pada program pancawardhana, yakni pembentukan moral, kecerdasan, emosional, keterampilan, dan jasmani menjadi kurikulum 1968 yang mengubah struktur pancawardhana menjadi pembinaan jiwa Pancasila, adalah contoh perubahan karena alasan politis. Persoalannya, apakah isu perubahan kurikulum 2006 menjadi kurikulum 2013 atau 2014 lebih karena persoalan politis? Benarkah isu perubahan kurikulum ini mulai diisyaratkan oleh tulisan wakil presiden Budiono di Kompas 27 Agustus 2012 bertajuk "Pendidikan Kunci Pembangunan" dan semakin jelas dengan kunjungan Menteri Luar Negeri US, Hillary Clinton yang membawa bantuan dana pendidikan yang besar?

Kiranya bukan pada kapasitasnya ketika seorang guru yang sehari-hari terlibat di lapangan berupaya menelisik isu perubahan kurikulum 2006 menjadi kurikulum 2013/2014 dari sudut pandang politik. Memahami KTSP (Kurikulum 2006) sebagai konsekuensi otonomi sekolah akibat pembagian kekuasaan antara pusat dan daerah (otonomi daerah) berikut landasan-landasan hukum (undang-undang sistem pendidikan nasional, standar nasional pendidikan, dll) dan filosofi pembelajaran konstruktivisme yang mendasari, sesungguhnyalah belum tuntas digumuli para guru. Kesempatan besar untuk merancang kurikulum yang khas masing-masing sekolah sejalan dengan visi-misi sekolah, sekarang ini justru masih terbelenggu oleh pemenuhan administrasi akibat penyempurnaan-penyempurnaan kebijakan yang tidak habis-habisnya dan tuntutan profesionalisme guru berikut kewajibankewajiban administrasinya.

\section{Esensi KTSP dan Pemahaman Kurikulum}

Pemahaman terhadap kurikulum sangat dipengaruhi oleh apa definisi atau batasan kurikulum. Secara teoritis, ada banyak pengertian kurikulum. Sesuai dengan kondisi guru sebagai pelaksana kurikulum di lapangan, kurikulum lebih tepat dimaknai dari dua sudat pandang. Sudut pandang pertama melihat kurikulum sebagai sebuah pedoman (dokumen). Pada konteks ini kurikulum dipahami sebagai seperangkat rencana dan pengaturan mengenai tujuan, isi, dan bahan pelajaran, serta cara yang digunakan sebagai pedoman aktivitas belajar mengajar untuk mencapai tujuan pendidikan. Sudut pandang kedua melihat kurikulum sebagai sebuah kegiatan (proses). Pada konteks ini, kurikulum dipahami sebagai segala aktivitas yang dilakukan sekolah dalam rangka pemengaruhi siswa dalam belajar untuk mencapai tujuan pembelajaran. Dengan kata lain, kurikulum tidak hanya dipahami sebagai suatu administrasi yang harus dilengkapi, tetapi kurikulum juga bermakna sebagai aktivitas (proses).

Kurikulum 2006 (KTSP) sebagai penyempurnaan kurikulum 2004 dengan sebutan Kurikulum Berbasis Kompetensi (KBK) yang merupakan reaksi atas kurikulum 1994 (revisi 1997) yang sangat mengedepankan materi (material-based) akibat berkembangnya teori pembelajaran kognitivis. Teori psikologi belajar yang melatarbelakangi KTSP adalah konstruktivisme. Untuk itulah perangkat-perangkat yang dicontohkan penyusun kurikulum, model asesmen yang digunakan, metode pembelajaran yang dikembangkan, langkah-langkah pembelajaran yang direkomendasikan, dan pembagian peran guru-siswa sungguh disemangati oleh spirit konstruktivisme.

Mengingat KTSP dilandasi oleh visi-misi masing-masing sekolah (yang antara sekolah satu dengan sekolah lain tentu berbeda) dan kurikulum pokok (standar isi) yang dirumuskan Badan Standar Nasional Pendidikan (BSNP) adalah materi minimal dan tingkat kompetensi minimal untuk mencapai kompetensi lulusan minimal, maka tentulah sekolah diberi keleluasaan untuk mengembangkan kurikulumnya. Para pengawas/penilik sekolah sebagai bagian dari dinas pendidikan daerah perlu sungguh memahami konteks ini. Bukan keseragaman format, harus begini, harus begitu yang perlu diobservasi, tetapi lebih kepada bagaimana pertanggungjawaban, nalar, pedagogik, profesionalisme yang perlu mendapat perhatian.

\section{Kurikulum 2013 untuk SMP}

\section{a. Organisasi Kompetensi}

Mata pelajaran adalah unit organisasi terkecil dari Kompetensi Dasar. Untuk kurikulum SMP/MTs, organisasi Kompetensi Dasar dilakukan dengan cara mempertimbangkan kesinambungan antarkelas dan keharmonisan antar mata pelajaran yang diikat dengan Kompetensi Inti. Berdasarkan pendekatan ini maka terjadi reorganisasi Kompetensi Dasar mata pelajaran sehingga struktur kurikulum SMP/MTs menjadi lebih sederhana karena jumlah mata pelajaran dan jumlah materi berkurang. Substansi muatan lokal termasuk bahasa daerah diintegrasikan ke dalam mata pelajaran Seni Budaya. Substansi muatan lokal yang berkenaan dengan olahraga serta permainan daerah diintegrasikan ke dalam mata pelajaran Pendidikan Jasmani, Olahraga, dan Kesehatan. Sedangkan Prakarya merupakan mata pelajaran yang berdiri sendiri.

\section{b. Tujuan Satuan Pendidikan}

Penyelenggaraan pendidikan dasar dan menengah sebagaimana yang dinyatakan dalam Peraturan Pemerintah Nomor 17 Tahun 2010 tentang Pengelolaan dan Penyelenggaraan Pendidikan bertujuan membangun landasan bagi berkembangnya potensi peserta didik agar menjadi manusia yang:

1) Beriman dan bertakwa kepada Tuhan Yang Maha Esa, berakhlak mulia, dan berkepribadian luhur;

2) Berilmu, cakap, kritis, kreatif, dan inovatif;

3) Sehat, mandiri, dan percaya diri; dan 
4) Toleran, peka sosial, demokratis, dan bertanggung jawab.

\section{c. Struktur Kurikulum dan Beban Belajar}

Tabel 1. Struktur Kurikulum 2013 untuk SMP/MTs

\begin{tabular}{|c|c|c|c|c|}
\hline \multirow{2}{*}{\multicolumn{2}{|c|}{ MLITAPELAMARAN }} & \multicolumn{3}{|c|}{$\begin{array}{c}\text { ALOKLSI WAKTE BEL WAR PER } \\
\text { AHVGGE }\end{array}$} \\
\hline & & vII & VIII & IX \\
\hline \multicolumn{5}{|c|}{ Kelompok A } \\
\hline 1. & Peschidican Aguma dan Budi Pekerti & 3 & 3 & 3 \\
\hline 2. & Pendidikan Pancasila dan Kewarganegarann & 3 & 3 & 3 \\
\hline k. & Bahasa Indooesis & 6 & 6 & 6 \\
\hline 4. & Matenatika & 5 & 5 & 5 \\
\hline 5: & Ilma Pengetahuan Ahm & 5 & 5 & 5 \\
\hline 6. & Ilexa Peugetalinan Sosial & 4 & 4 & 4 \\
\hline 7. & Bahasa Inggis & 4 & 4 & 4 \\
\hline \multicolumn{5}{|c|}{ Kelompak B } \\
\hline 1. & Seri Buatuya & 3 & 3 & 3 \\
\hline 2. & $\begin{array}{l}\text { Pendidikan Jasmain, Olah Raga, dan } \\
\text { Keschatan }\end{array}$ & 3 & 3 & 3 \\
\hline 3. & Prakarya & 2. & 2 & 2 \\
\hline Jit & mish Alokas Wakna Per Mingen & 38 & 38 & 38 \\
\hline
\end{tabular}

Keterangan

Mats peinjanan Seai Budrya dapat memuat Bahasa Dacrah.

\section{B. Sikap Profesional Guru}

Guru sebagai pendidik professional mempunyai citra yang baik dimasyarakat apabila dapat menunjukkan kepada masyarakat bahwa ia layak menjadi panutan atau teladan masyarakat sekelilingnya. Masyarakat akan melihat bagaimana sikap dan perbuatan guru itu sehari-hari, apakah memang ada yang patut diteladani atau tidak. Bagaimana guru meningkatkan pelayanannya, meningkatkan pengetahuannya, memberi arahan dan dorongan kepada anak didiknya, dan bagaimana cara guru berpakaian dan berbicara serta cara bergaul baik dengan siswa, temantemannya serta anggota masyarakat, sering menjadi perhatian masyarakat luas.

Pengertian sikap guru berasal dari dua kata, yaitu sikap dan guru. Sikap (attitude) adalah kecenderngan secara relative stabil dan menetap untuk bertingkah laku atau bereaksi dengan suatu cara tertentu terhadap orang-orang, obyek-obyek, pranata-pranata, atau persoalanpersoalan, Komaruddin (1994:44).

Dipandang dari sudut lain sikap (attitude) merupakan kecenderungan untuk bereaksi terhadap orang, pranata, atau peristiwa secara positif atau negative. Sikap secara khas mengandung arti kecenderungan untuk mengklasifikasi atau mengkategorisasi sesuatu, Komaruddin (1994:44).

Sedangkan guru menurut Balnadi Sutadipura adalah orang yang layak digugu dan ditiru, Sutadi (1983:54). Menurut Persatuan Guruguru Amerika Serikat, guru adalah semua petugas yang terlibat dalam tugas-tugas kependidikan, (Roestiyah 1982 ;182). Menurut Kamus Besar Bahasa Indonesia, guru adalah orang yang pekerjaannya (mata penchariannya, profesinya) mengajar, (Moeliono, 1988:288).

Walaupun segala perilaku guru selalu diperhatikan masyarakat, tetapi yang akan dibicarakan dalam bagian ini adalah khusus perilaku guru yang berhubungan dengan profesinya. Hal ini berhubungan dengan bagaimana pola tingkah laku guru dalam memahami, menghayati, serta mengamalkan sikap kemampuan dan sikap profesionalnya. Pola tingkah laku guru yang berhubungan dengan itu akan dibicarakan sesuai dengan sasarannya, yakni sikap professional keguruan terhadap:

a. Peraturan perundang-undangan,

b. Organisasi profesi,

c. Teman sejawat, d. Anak didik,

e. Tempat kerja,

f. Pemimpin, dan

g. Pekerjaan.

\section{Metode}

Penelitian ini menggunakan metode penelitian kualitatif dengan menggunakan pendekatan jenis etnografi. Penelitian ini mengeksplor fenomena-fenomena yang bersifat deskriptif tentang perubahan kurikulum 2013 terhadap sikap profesional guru penjasorkes dalam menjalankan tugasnya. Peneliti menggunakan teknik Purposive Sampling dan Snowball Sampling dalam menentukan subjek penelitian/ informan, informan pertama yaitu guru Penjasorkes yang bertugas di SMPN 1 Kutawaluya Kabupaten Karawang.

Jenis Data Penelitian yang digunakan yaitu buku catatan, rekaman video, dokumentasi, dan foto. Pengumpulan data dilakukan dengan teknik observasi, wawancara, dan studi dokumentasi. Teknik analisis data dalam penelitian ini menggunakan Model Sirkuler Nasution, yaitu pertanyaan penelitian, pengumpulan data, analisis data, verifikasi, dan laporan berdasarkan catatan dan ingatan. Keabsahan data dilakukan dengan triangulasi kepada kepala sekolah, rekan guru, dan siswa.

\section{Hasil dan Pembahasan}

Penelitian ini untuk mengungkap bagaimana perubahan kurikulum 2013 terhadap sikap profesional guru penjasorkes SMP di Kabupaten Karawang sehingga diperoleh hasil penelitian sebagai berikut:

1. Sebagian besar informan yaitu $63 \%$ menyatakan perubahan kurikulum 2013 berpengaruh positif terhadap sikap profesional guru Penjasorkes Sekolah Menengah Pertama di Kabupaten Karawang. Perubahan kurikulum yang terjadi dapat dijadikan awal perubahan dalam dirinya untuk menjadi pendidik yang lebih berkembang menyesuaikan zaman. Bersikap menerima pekerjaan dalam hal pembaruan yang lebih menantang menjadi pilihan informan sebagai para pendidik.

2. Sebagian kecil informan yaitu $37 \%$ menyatakan, perubahan kurikulum 2013 berpengaruh negatif terhadap sikap profesional guru Penjasorkes Sekolah Menengah Pertama di Kabupaten Karawang. Perubahan kurikulum yang terjadi memungkinkan para guru merasa terbebani oleh hadirnya kurikulum baru. Setiap pergantian kebijakan pendidikan, yang selalu paling direpotkan adalah para guru. Selain harus belajar lagi lantaran ada pergantian buku-buku pelajaran, guru dituntut membaca dan mengubahnya menjadi rencana pembelajaran harian kepada peserta didik. Sehingga sikap guru terhadap pekerjaan tergolong tidak terbuka dalam menerima pembaharuan.

\section{Simpulan dan Rekomendasi}

Sebagian besar informan menyatakan, Perubahan Kurikulum 2013 Berpengaruh Positif terhadap Sikap Profesional Guru Penjasorkes Sekolah Menengah Pertama di Kabupaten Karawang dan sebagian kecil informan menyatakan, Perubahan Kurikulum 2013 Berpengaruh Negatif terhadap Sikap Profesional Guru Penjasorkes Sekolah Menengah Pertama di Kabupaten Karawang. Perubahan kurikulum yang terjadi bagi sebagian besar informan dijadikan awal perubahan dalam dirinya untuk lebih menjadi pendidik yang lebih baik dan berkembang menyesuaikan zaman Sedangkan perubahan kurikulum yang terjadi bagi sebagian kecil informan menjadikan para guru merasa terbebani oleh hadirnya kurikulum baru.

Berdasarkan hasil penelitian tersebut, maka disarankan sebagai berikut 1) Dinas Pendidikan pusat maupun daerah mengadakan sosialisasi lebih dulu kepada para guru jika akan terjadi perubahan kurikulum, dan dilanjutkan diklat-diklat yang bertahap dan berkelanjutan hingga pemberlakuan kurikulum baru tersebut. Sehingga guru dapat menjalankan 
perubahan secara utuh dan menyeluruh. 2) Kepala Sekolah hendaknya pelatihan khusus guru pendidikan jasmani olahraga dan kesehatan, agar guru penjas senantiasa memiliki kemampuan yang baik dalam mengimplementasikan kuruing baru secara kreatif dan inovatif. 3) Guru pendidikan jasmani olahraga dan kesehatan hendaknya lebih terbuka dalam menghadapi suatu perubahan kearah yang lebih baik untuk kepentingan profesionalisme, kualitas pembelajaran, dan peningkatan prestasi siswa yang optimal.

\section{Referensi}

Djam'an Sutori. 2009. Metodologi Penelitian Kualitatif, Bandung: Alfabeta.

Nana Sudjana. 2010. Penilaian Hasil Proses Belajar Mengajar, Bandung:PT. Remaja Rosdakarya. mengikutsertakan guru penjas kedalam beberapa acara seminar dan Nasution. 1988. Metode Penelitian Naturalistik Kualitatif, Bandung: Tarsito.

Nurdin, Syafruddin. 2005. "Guru Profesional \& Implementasi Kurikulum”, Cetakan Ketiga, Quantum Teaching.

Soetjipto dan Raflis Kosasi. 2004. "Profesi Keguruan", Cetakan kedua, PT. Rineka Cipta.

Suharsimi Arikunto. 2002. Prosedur Penelitian: Suatu Pendekatan Praktek, Jakarta: PT. Rineka Cipta.

Sukintaka. 2004. Teori Pendidikan Jasmani, Bandung: Nuansa.

Suryabrata, Sumardi. 2002. "Psikologi Pendidikan”, Cetakan Ke-2, PT. Raja Grafindi Persada. 